\title{
Is More Regulation Really the Best Answer to the Financial Crisis?
}

\author{
by Jakob de Haan
}

\begin{abstract}
This contribution discusses some recent research on the relationship between financial liberalisation and banking crises. Using a new database of financial liberalisation, the widely-shared view that deregulation increases the probability of a systemic banking crisis is questioned. A recent example of unwarranted legislation, namely the regulation on credit rating agencies (CRAs) in the EU, is used to illustrate this point. As CRAs have been severely criticised for their use of inadequate data, flawed modelling, considerable time lags in the reduction of ratings and an insufficient level of communication with the users of credit ratings (negatively affecting confidence), various policymakers expressed a desire to regulate CRAs. This contribution argues that the EU regulation on the ratings of CRAs is not defensible and may lead investors to outsource their due diligence.
\end{abstract}

Dieser Beitrag summiert neue Erkenntnisse zur Wechselwirkung von liberalisierten Finanzmärkten und der Entstehung von Bankenkrisen. Unter Rückgriff auf eine neue Datenbank zur Finanzmarktliberalisierung wird die weit verbreitete Meinung in Frage gestellt, nach der die Wahrscheinlichkeit von Bankenkrisen positiv mit zunehmender Liberalisierung der Finanzmärkte ansteigt. Als neueres Beispiel ungerechtfertigter Regulierung wird die EU-Verordnung zu Ratingagenturen (CRAs) angeführt. Da CRAs aus unterschiedlichen Gründen stark in die Kritik gerieten (unvollständige Datensätze, fehlerhafte Berechnungsmodelle, Zeitverzögerungen), wird häufig ihre Regulierung gefordert. Dennoch ist die EU-Verordnung nur mangelhaft empirisch gerechtfertigt und könnte sogar zu falschen Anreize für Investoren führen.

\section{Introduction}

Nowadays many observers seem to believe that financial liberalisation has played an important role in creating the current financial crises. Indeed, there is some evidence that financial liberalisation induces risk-taking behaviour and may cause banking crises. ${ }^{1}$ Consequently, policymakers in most industrial countries

1 Cf. Kaminsky, G./Reinhart, C.: The Twin Crises: The Causes of Banking and Balance-Of-Payments Problems, in: American Economic Review, $89 / 3$ (1999), 473-500; Mehrez, G./Kaufman, D.: Transparency, Liberalization and Banking Crises, World Bank Policy Research Working Paper No. 2286, 2000; Demirgüç-Kunt, A./Detragiache, E.: Financial Liberalization and Financial Fragility, World Bank Policy Research Working Paper No. 1917, 1998. 
have come up with proposals for 'better' regulation of the financial system. Notably in the European Union (EU), policymakers want to be seen acting swiftly and decisively in time of crisis, thereby capturing the new Zeitgeist of legislative intervention in the economic sphere. However, the effectiveness of some recent initiatives for new regulation of financial institutions may be questioned.

In addition, Allen/Gale point out that the extensive financial regulation introduced after the Great Depression not only led to the virtual disappearance of crises, it also seriously affected the efficiency of the financial system. ${ }^{2}$ They argue that the complete elimination of crises is neither optimal nor desirable, because it reduces the ability of financial institutions to perform their basic task of efficient allocation of resources.

In this contribution I will first discuss some recent research on the relationship between financial liberalisation and banking crisis. Using a new database of financial liberalisation recently provided by Abiad et al., ${ }^{3}$ both Angkinand et al. and Shezhad/De Haan question the widely-shared view that financial liberalisation increases the probability of a systemic banking crisis. ${ }^{4}$ I will then turn to an example of recent regulation that in my view is unwarranted, namely the recently adopted regulation of credit rating agencies (CRAs) in the EU. CRAs have been severely criticised as they assigned high ratings to complex structured sub-prime debt based on inadequate historical data and in some cases flawed models. Moreover, once the problems in the sub-prime market became clear, CRAs responded with a considerable time lag in reducing their ratings. Criticism has also been raised concerning the agencies' communication with users of credit ratings, affecting market participants' confidence in the performance of credit rating agencies and the reliability of their ratings. No wonder therefore, that various policymakers expressed a desire to regulate CRAs. Amtenbrink/De Haan argue, however, that the recently adopted EU regulation on the ratings of CRAs is not warranted, and in fact, may only increase the tendency of investors to outsource their due diligence to rating agencies. ${ }^{5}$

2 Allen, F./Gale, D.: Understanding Financial Crises, Oxford, 2007.

3 Abiad, A./Tressel, T./Detragiache, E.: A New Database of Financial Reforms, IMF Working Paper No. 08/266, 2008.

4 Angkinand, A./Sawangngoenyuang, W./Wihlborg, C.: Financial Liberalization and Banking Crises: A Cross-Country Analysis, SSRN Working Paper Series, 2009; Shehzad, C./De Haan, J.: Financial Reform and Banking Crises, CESifo Working Paper No. 2870, 2009.

5 Amtenbrink, F./De Haan, J.: Regulating Credit Ratings in the European Union: A Critical First Assessment of Regulation 1060/2009 on Credit Rating Agencies, in: Common Market Law Review, 46 (2009), forthcoming. 


\section{Does Financial Liberalisation Really Lead to Banking Crises?}

Previous studies on the impact of financial liberalisation on banking crises used indicators of liberalisation that were quite limited and rather subjective. As pointed out by Angkinand et al., most of these studies capture periods of nonliberalised and liberalised financial systems using a $0 / 1$ variable. ${ }^{6}$ The finding that liberalisation is preceding banking crises may, however, capture "a truism since some degree of liberalisation is probably required for losses in the banking system to be manifested as a banking crisis. A highly repressed banking system may perform very poorly and still survive based on different forms of more or less overt state support." ${ }^{, 7}$ Some other studies use indicators of liberalisation that reflect the outcomes of liberalisation. For instance, Bekeart et al. proxy liberalisation by market capitalisation. ${ }^{8}$

Both Angkinand et al. and Shezhad/De Haan use an extensive new data set of financial liberalisation recently provided by Abiad et al. ${ }^{9}$ This is an extended and updated version of the database as used by Abiad/Mody, ${ }^{10}$ covering six dimensions of the extent to which the financial sector has been liberalised that are graded on a scale from 3 (fully liberalised) to 0 (not liberalised). Apart from distinguishing between different dimensions of financial liberalisation on an annual basis, the database has the advantage that it allows for policy reversals.

The first dimension of liberalisation refers to credit controls and excessively high reserve requirements (referred to as credit controls henceforth) focusing on the presence of specific credit ceilings or floors, and reserve requirements. The second dimension is about interest rate controls examining whether they are administered by the government, and whether there are floors, ceilings or bands present. The third dimension is entry barriers, which is based on licensing requirements and restrictions on geographical outreach activities. The fourth dimension covers state ownership in the banking sector, i.e., the share of the assets of the banking sector controlled by state-owned banks. The fifth dimension refers to capital account restrictions and other restrictions on international

6 Angkinand, A./Sawangngoenyuang, W./Wihlborg, C., op. cit.

7 Ibid, 2-3.

8 Bekaert, G./Harvey, C./Lundblad, C.: Growth Volatility and Financial Liberalization, in: Journal of International Money and Finance, 25/3 (2006), 370-403.

9 Abiad, A./Tressel, T./Detragiache, E., op. cit.; Angkinand, A./Sawangngoenyuang, W./Wihlborg, C., op. cit.; Shehzad, C./De Haan, J., op. cit.

10 Abiad, A./Mody, A.: Financial Reform: What Shakes It? What Shapes It?, in: American Economic Review, 95/1 (2005), 66-88. 
capital flows. The final dimension refers to securities market policy covering the auctioning of government securities, debt and equity market development, and openness to foreign investors. The database also provides a proxy for supervisory control, capturing prudential regulations and supervision of the banking sector, including compliance with the Basel standards, and executive influence on the banking supervisory agency.

Figure 1 shows the different financial liberalisation and supervision measures over the period of 1973-2005, differentiating between high-income OECD countries and other countries. As follows from Figure 1, the average level of financial liberalisation has increased over time, but the financial systems of high-income OECD countries are more liberalised than those of other countries in the sample and they are better supervised as well. Still, the gap between the two groups of countries has decreased over the 1973-2005 period for all liberalisation dimen-

Figure 1: Financial liberalisation in high-income OECD and other countries
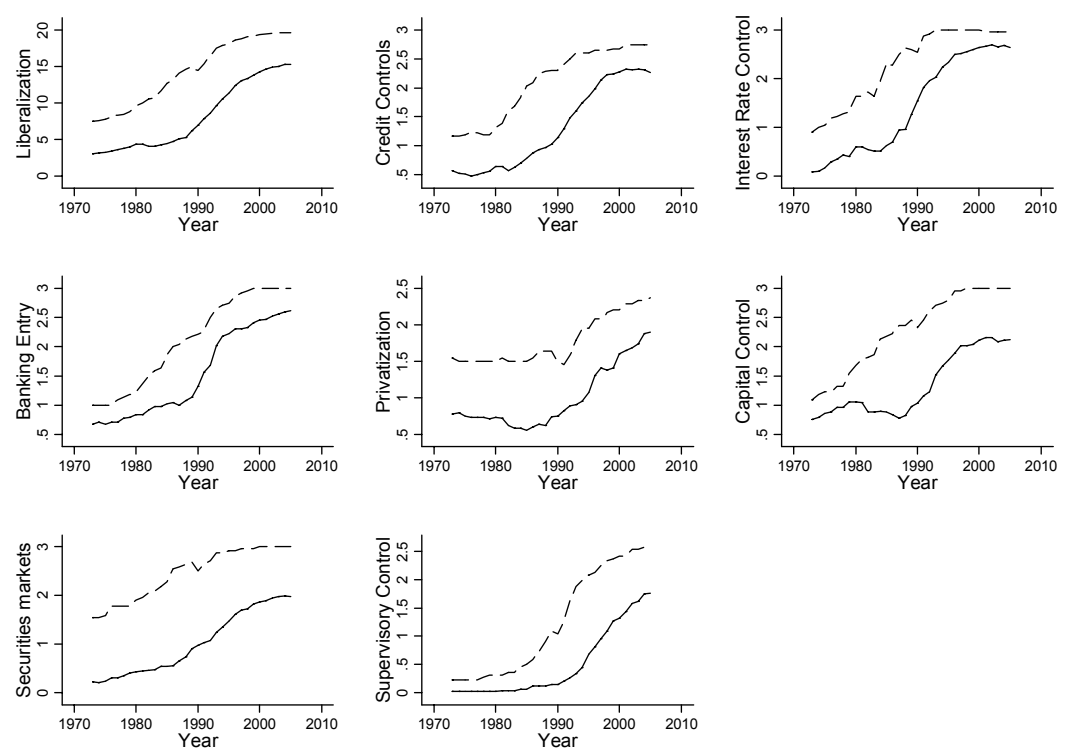

Source: Shehzad, C./De Haan, J., op. cit.

Notes: Period 1973-2005; dashed lines: high-income OECD countries; solid lines: other countries of the sample. 
sions, except for securities markets and capital controls. However, while financial systems in non-high-income OECD countries have been liberalised substantially, their supervisory control systems have evolved more slowly and the gap with high-income OECD countries has increased.

Angkinand et al. and Shezhad/De Haan analyse whether the relationship between liberalisation of the financial sector and banking crisis holds for different dimensions of liberalisation and whether it depends on institutional characteristics of the liberalising country. ${ }^{11}$ Both examine whether the impact of financial liberalisation on banking crises is conditioned by the effectiveness of supervision, while Angkinand et al. also take the existence of deposit insurance and the quality of institutions in the liberalising country into account. The studies differ in various respects, the most important one being that Angkinand et al. focus on a nonlinear relationship between liberalisation and banking crisis, whereas Shezhad/ De Haan focus on the interaction between liberalisation, supervision and banking crises. The samples of the two studies are also different. Whereas Angkinand et al. use data for 48 countries, Shezhad/De Haan employ data for 85 countries. Despite these differences, both studies come to very similar conclusions, the main one being that the view that liberalisation causes banking crises needs to be reconsidered.

Table 1 is reproduced from Angkinand et al. ${ }^{12}$ The dependent variable is a dummy indicating whether there is a banking crisis or not. ${ }^{13}$ These authors include the level of liberalisation (Total FL) as well liberalisation squared to examine non-linearities in the relationship between liberalisation and banking crises. Apart from various macro-economic control variables, also capital regulation and supervision of banks (CRS) and deposit insurance systems (DI coverage) are included. The latter variable measures the maximum deposit insurance coverage in a country relative to the value of the average (per capita) deposit. The macro controls are the real GDP growth rate, the ratio of current account to GDP, the ratio of money supply to international reserves, the growth rate of the ratio of domestic credit provided by banking sector to GDP, the ratio of capital flows to GDP, the inflation rate, the weighted average of the interest rates in Germany,

11 Angkinand, A./Sawangngoenyuang, W./Wihlborg, C., op. cit.; Shehzad, C./De Haan, J., op. cit.

12 Angkinand, A./Sawangngoenyuang, W./Wihlborg, C., op. cit.

13 Cf. Caprio, G. Jr. et al.: Banking Crisis Database, in: Honohan, P./ Laeven, L. (eds.): Systemic Financial Crises: Containment and Resolution, Cambridge, 2005, 307-340. 
Table 1: A non-linear relationship between financial liberalisation and banking crises

\begin{tabular}{|c|c|c|c|c|c|c|}
\hline Sample & $\begin{array}{c}(1) \\
A L L\end{array}$ & $\begin{array}{c}(2) \\
\text { ALL }\end{array}$ & $\begin{array}{c}(3) \\
\mathrm{ADV}\end{array}$ & $\begin{array}{c}(4) \\
\mathrm{ADV}\end{array}$ & $\begin{array}{c}\text { (5) } \\
\text { EMG }\end{array}$ & $\begin{array}{c}\text { (6) } \\
\text { EMG }\end{array}$ \\
\hline Total FL $\mathrm{FL}_{\mathrm{t}-1}$ & $\begin{array}{c}0.004^{* *} \\
(0.003)\end{array}$ & $\begin{array}{l}0.011 * * \\
(0.001)\end{array}$ & $\begin{array}{c}0.004^{* *} \\
(0.003)\end{array}$ & $\begin{array}{c}0.016^{* * *} \\
(0.001)\end{array}$ & $\begin{array}{c}0.004^{* *} \\
(0.032)\end{array}$ & $\begin{array}{c}0.016 * * \\
(0.001)\end{array}$ \\
\hline$\left(\text { Total FL } \mathrm{t}_{\mathrm{t}-1}\right)^{2}$ & & $\begin{array}{c}-0.0004^{* *} \\
(0.026)\end{array}$ & & $\begin{array}{c}-0.001 * * \\
(0.017)\end{array}$ & & $\begin{array}{c}-0.001 * * \\
(0.005)\end{array}$ \\
\hline $\mathrm{CRS}_{\mathrm{t}-1}$ & $\begin{array}{c}-0.017^{* *} \\
(0.004)\end{array}$ & $\begin{array}{l}-0.010^{\#} \\
(0.140)\end{array}$ & $\begin{array}{l}-0.006^{\#} \\
(0.320)\end{array}$ & $\begin{array}{l}-0.001 \\
(0.797)\end{array}$ & $\begin{array}{c}-0.037 * * \\
(0.008)\end{array}$ & $\begin{array}{l}-0.022^{\#} \\
(0.105)\end{array}$ \\
\hline DI Coverage $e_{t-1}$ & $\begin{array}{l}0.0004 \\
(0.715)\end{array}$ & $\begin{array}{c}0.001 \\
(0.594)\end{array}$ & $\begin{array}{c}0.001 \\
(0.576)\end{array}$ & $\begin{array}{l}0.0001 \\
(0.875)\end{array}$ & $\begin{array}{l}0.0002 \\
(0.922)\end{array}$ & $\begin{array}{c}0.001 \\
(0.471)\end{array}$ \\
\hline GDP/Capita $a_{t-1}$ & $\begin{array}{c}-0.010^{* *} \\
(0.011)\end{array}$ & $\begin{array}{c}-0.011^{* *} \\
(0.004)\end{array}$ & $\begin{array}{l}0.020^{\#} \\
(0.128)\end{array}$ & $\begin{array}{l}0.015^{\#} \\
(0.136)\end{array}$ & $\begin{array}{l}0.007 \\
(0.353)\end{array}$ & $\begin{array}{c}0.006 \\
(0.376)\end{array}$ \\
\hline GDP Growth Rate $_{t-1}$ & $\begin{array}{c}-0.259^{* * *} \\
(0.016)\end{array}$ & $\begin{array}{c}-0.244^{* *} \\
(0.012)\end{array}$ & $\begin{array}{c}-0.041 \\
(0.883)\end{array}$ & $\begin{array}{l}-0.038 \\
(0.879)\end{array}$ & $\begin{array}{c}-0.470 * * \\
(0.005)\end{array}$ & $\begin{array}{c}-0.425^{* *} \\
(0.005)\end{array}$ \\
\hline $\mathrm{CA} / \mathrm{GDP}_{\mathrm{t}-1}$ & $\begin{array}{c}-0.272^{* *} \\
(0.012)\end{array}$ & $\begin{array}{c}-0.258 * * \\
(0.012)\end{array}$ & $\begin{array}{c}-0.206^{*} \\
(0.089)\end{array}$ & $\begin{array}{l}-0.196 * \\
(0.064)\end{array}$ & $\begin{array}{c}-0.329 * * \\
(0.036)\end{array}$ & $\begin{array}{c}-0.304 * * \\
(0.033)\end{array}$ \\
\hline M2/Reserves ${ }_{t-1}$ & $\begin{array}{l}0.009^{\#} \\
(0.135)\end{array}$ & $\begin{array}{l}0.009 * \\
(0.095)\end{array}$ & $\begin{array}{c}0.005 \\
(0.339)\end{array}$ & $\begin{array}{l}0.007^{\#} \\
(0.178)\end{array}$ & $\begin{array}{c}0.023^{* *} \\
(0.010)\end{array}$ & $\begin{array}{c}0.023 * * \\
(0.004)\end{array}$ \\
\hline Credit Growth $_{\mathrm{t}-1}$ & $\begin{array}{c}0.053^{* *} \\
(0.000)\end{array}$ & $\begin{array}{l}0.050^{* * *} \\
(0.000)\end{array}$ & $\begin{array}{c}0.009 \\
(0.723)\end{array}$ & $\begin{array}{c}0.008 \\
(0.761)\end{array}$ & $\begin{array}{c}0.077 * * \\
(0.004)\end{array}$ & $\begin{array}{c}0.069 * * \\
(0.003)\end{array}$ \\
\hline Capital Flows/GDP ${ }_{t-1}$ & $\begin{array}{c}0.274^{* *} \\
(0.016)\end{array}$ & $\begin{array}{l}0.272^{* * *} \\
(0.020)\end{array}$ & $\begin{array}{c}0.095 \\
(0.397)\end{array}$ & $\begin{array}{c}0.043 \\
(0.719)\end{array}$ & $\begin{array}{c}0.374^{* *} \\
(0.032)\end{array}$ & $\begin{array}{c}0.413 * * \\
(0.017)\end{array}$ \\
\hline Inflation $_{t-1}$ & $\begin{array}{c}0.036^{* *} \\
(0.000)\end{array}$ & $\begin{array}{l}0.032^{* * *} \\
(0.000)\end{array}$ & $\begin{array}{l}0.231^{*} \\
(0.099)\end{array}$ & $\begin{array}{l}0.225^{*} \\
(0.057)\end{array}$ & $\begin{array}{c}0.027 * * \\
(0.005)\end{array}$ & $\begin{array}{c}0.019 * * \\
(0.030)\end{array}$ \\
\hline Northern Interest Rate $t-1$ & $\begin{array}{c}0.481^{* *} \\
(0.017)\end{array}$ & $\begin{array}{l}0.524^{* *} \\
(0.007)\end{array}$ & $\begin{array}{l}0.450^{*} \\
(0.065)\end{array}$ & $\begin{array}{l}0.320^{\#} \\
(0.180)\end{array}$ & $\begin{array}{l}0.461^{*} \\
(0.089)\end{array}$ & $\begin{array}{c}0.520^{* *} \\
(0.042)\end{array}$ \\
\hline Currency Crises $_{t-1}$ & $\begin{array}{l}-0.008 \\
(0.465)\end{array}$ & $\begin{array}{l}-0.008 \\
(0.448)\end{array}$ & $\begin{array}{c}0.008 \\
(0.595)\end{array}$ & $\begin{array}{c}0.007 \\
(0.606)\end{array}$ & $\begin{array}{l}-0.025 * \\
(0.073)\end{array}$ & $\begin{array}{l}-0.023 * \\
(0.062)\end{array}$ \\
\hline No of Obs & 1089 & 1089 & 536 & 536 & 553 & 553 \\
\hline Wald Chi-Square & 92.195 & 96.563 & 82.325 & 88.162 & 117.797 & 196.452 \\
\hline Prob $>$ Chi-Square & 0.000 & 0.000 & 0.000 & 0.000 & 0.000 & 0.000 \\
\hline
\end{tabular}

The dependent variable is the onset of banking crisis dummy. Regressions are estimated using the Logit model with robust and clustered standard errors within a country. ${ }^{*}, * *$ indicate the significance levels of $10 \%$ and $5 \%$, respectively. ${ }^{*}$ indicates the coefficient value zero that falls outside one standard deviation of the estimate. The numbers in parentheses are p-values. For sample, $\mathrm{ALL}=$ all sample $\mathrm{ADV}=\mathrm{Advanced}$ economies, $\mathrm{EMG}=$ Emerging markets.

Source: Angkinand, A./Sawangngoenyuang, W./Wihlborg, C., op. cit.

USA, UK, Switzerland, France and Japan (the Northern interest rate), and a currency crisis dummy.

Columns (1), (3) and (5) of Table 1, where a linear relationship between Total FL and the occurrence of banking crisis is assumed, are consistent with the conventional wisdom that increased financial liberalisation is associated with a higher likelihood of banking crisis. The coefficient for Total FL is positive and 
strongly significant in the regressions for all countries (ALL), advanced countries (ADV) as well as emerging market countries (EMG). However, the results reported columns (2), (4) and (6) indicate that the conventional wisdom needs to be nuanced as there appears an inverted U-shaped relationship as shown by the significant, negative coefficients for Total FL squared in regressions for all countries as well as for the sub-samples.

Shezhad/De Haan examine the impact of what they call financial reform on banking crises. ${ }^{14}$ The likelihood of a crisis in country $i$ at time $t$ is a function of the initial level of liberalisation; reform, defined as the cumulative change in the level of liberalisation over the current and last four years period; the level of supervisory control; and a matrix of control variables. The control variables included are real GDP growth (one-year lagged), the rate of inflation (change in $\mathrm{CPI}$ ), the real interest, the depreciation of the exchange rate, and the initial level of real GDP per capita (in US\$). To check for the conditioning effect of banking supervision, Shezhad/De Haan introduce an interaction term of financial reform with the level of supervision. However, models with interactive terms cannot be interpreted directly on the basis of the coefficients of the constituent or interaction terms and their significance. ${ }^{15}$ Therefore, Shezhad/De Haan follow the approach suggested by Aiken/West for non-linear models. ${ }^{16}$ Figure 2 is reproduced from their study. It shows the marginal effects of financial reforms and their confidence intervals (at $5 \%$ level of significance). For a marginal effect of reform to be significantly positive (or negative), the marginal effect as well as the upper and lower bound should be in a positive (or negative) quadrant. As the figures show, when supervisory control improves, financial reform reduces the likelihood of systemic crises and this effect is significant especially at higher levels of supervisory control. However, this conclusion does not hold for reforms improving bank entry and securities market reforms, which appear insignificant. Consequently, the results of Shezhad/De Haan suggest that most dimensions of financial reform reduce the likelihood of systemic crises, conditional on adequate banking supervision.

14 Shehzad, C./De Haan, J., op. cit.

15 Aiken, L./West, S.: Multiple Regression: Testing and Interpreting Interactions, London, 1991; Brambor, T., Clark, W.R./Golder, M.: Understanding Interaction Models: Improving Empirical Analyses, in: Political Analysis, 14/1 (2006), 63-82; Shehzad, C./De Haan, J./Scholtens, B.: The Impact of Bank Ownership Concentration on Impaired Loans and Capital Adequacy, in: Journal of Banking and Finance, 34/2 (2010), 399-408.

16 Aiken, L./West, S., op. cit. 
Figure 2: Effect of financial reform on systemic banking crises at different levels of supervisory control
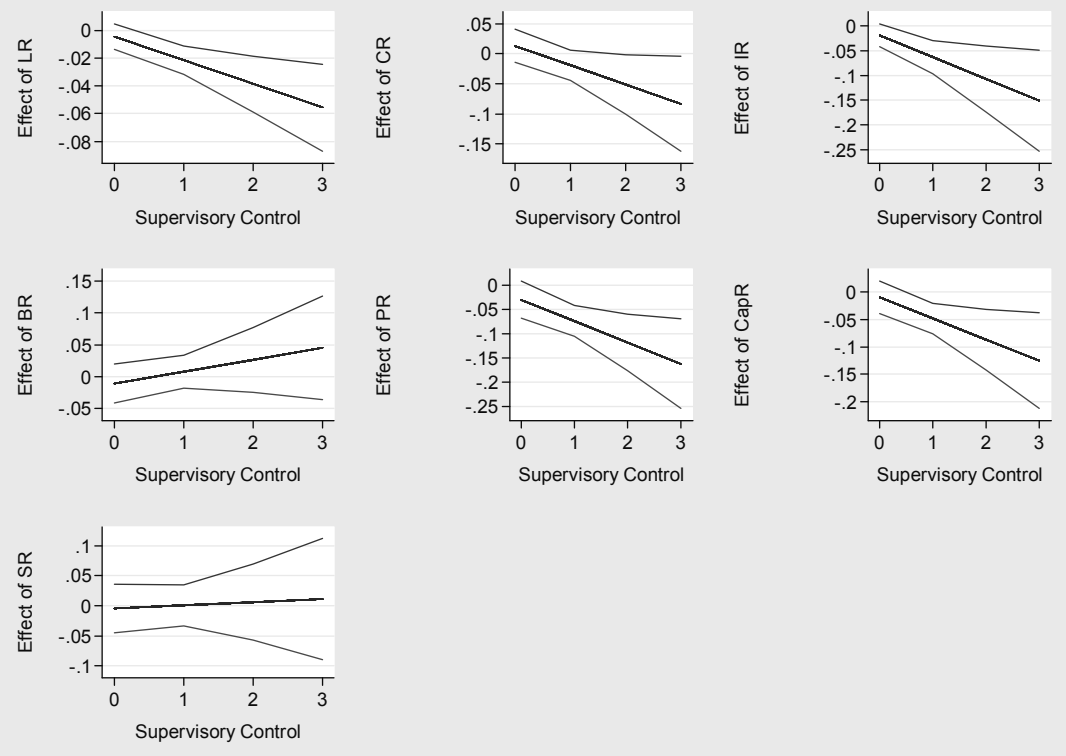

Source: Shehzad, C./De Haan, J., op. cit.

Notes: Middle line: effect of a particular dimension of reform; upper and lower lines: upper and lower $95 \%$ confidence intervals; LR: overall reform; CR: credit control reform; IR: interest rate control reform; BR: banking entry reform; PR privatisation reform; CapR capital control reform; SR: securities market reform.

\section{Superfluous Regulation: an Example ${ }^{17}$}

Credit Rating Agencies assess the credit risks of borrowers (governments, financial, and non-financial firms). The three largest competitors share roughly $95 \%$ of the market. Standard \& Poor's Ratings Services and Moody's Investors Service - both based in the United States - share $80 \%$ of the market, while UKbased Fitch Ratings holds $15 \%{ }^{18}$

17 The basic structure of the following argument is derived from a previous paper, Amtenbrink, F./De Haan, J., op. cit.

18 Daenen, P.: Rating and Regulation: Current Turbulent Conditions Could Be an Opportunity to Reform, paper presented at the 2008 Finlawmetrics Conference, Bocconi University, Milan, Italy, 12./13.06. 2008. 
In November 2008, the European Commission published a proposal for a Regulation on CRAs. With this proposal the Commission aimed at ensuring " $[\ldots]$ that credit ratings used in the Community are independent, objective and of the highest quality." 19 The European Parliament (EP) and the Council of the European Union approved the proposal. Before, CRAs were governed by the "Code for Conduct Fundamentals for Credit Rating Agencies' of the International Organisation of Securities Commissions (IOSCO). ${ }^{20}$ This IOSCO code has recently been updated in the wake of the global financial turmoil. ${ }^{21}$ However, this code is not binding: CRAs are merely invited to give reasons if they do not comply with the code (the "comply or explain" approach). The Committee of European Securities Regulators (CESR), an independent advisory group to the Commission composed of the national supervisors of EU securities markets, reports each year to the Commission on the extent to which CRAs adhere to this code of conduct. ${ }^{22}$ According to CESR, the IOSCO Code is "[...] the standard on which CRA conduct of business should be assessed [...]."23

In response to the crisis, several expert bodies have made concrete proposals for reforms. For instance, the Financial Stability Forum (FSF) recommended that CRAs should improve the quality of the rating process and should differentiate ratings on complex structured credit products from those on 'regular' bonds as these ratings have different risk properties. However, the FSF did not propose a new supervisory regime for CRAs. Instead, it advised that "Authorities will monitor, individually or collectively, the implementation of the revised IOSCO Code of Conduct by CRAs, in order to ensure that CRAs quickly translate it into action. ${ }^{24}$ Likewise, CESR emphasised that "CESR and market participants believe that there is no evidence that regulation of the credit rating industry would

19 European Commission: Proposal of the European Parliament and of the Council on Credit Rating Agencies, COM (2008) 704 final, 12.11. 2008, Preamble.

20 IOSCO membership is primarily made up of national central banks and financial market regulatory and supervisory agencies.

21 IOSCO Technical Committee: Code of Conduct Fundamentals for Credit Rating Agencies, revised version of May 2008, available at http:/www.iosco.org/library/pubdocs/pdf/IOSCOPD271.pdf.

22 Cf. CESR: CESR's Second Report to the European Commission on the compliance of credit rating agencies with the IOSCO Code and The role of credit rating agencies in structured finance, May 2008, available at http://www.cesr-eu.org/popup2.php?id=5049.

23 Ibid, 3.

24 Financial Stability Forum: Report of the FSF on Enhancing Market and Institutional Resilience, 07.04 $2008,58$. 
have had an effect on the issues which emerged with ratings of US subprime backed securities and hence continues to support market driven improvement". ${ }^{25}$

Even though the European Commission considers the revised IOSCO code of conduct to be "the global benchmark", it maintains that its substance has to be made more specific, to make it easier to apply in practice, and more efficient. In its own perception, the Commission thus opts for more robust, stringent and enforceable rules.

Amtenbrink/De Haan have analysed four main elements of the Regulation, including the scope of the Regulation, the registration of CRAs, the rules of conduct applicable to registered CRAs, and the envisaged enforcement regime. ${ }^{26}$ While it is impossible to answer the question with full certainty what would have happened if the Regulation had been in place, they argue that the behaviour of CRAs would hardly have been different during the recent financial crisis had the Regulation been in place. The main difference that the Regulation would have implied is that the CRAs should have made it clear that their ratings of the securitised instruments were not comparable to their ratings of other non-securitised instruments. Yet it is doubtful, whether this would have prevented investors from buying those instruments. Furthermore, the revised IOSCO code of Conduct also contains this rule.

In fact, Amtenbrink/De Haan argue that the Regulation could have exactly the effect opposite to its aim, namely that the "[...] users of credit ratings should not rely blindly on credit ratings but should take utmost care to perform own analysis and conduct appropriate due diligence at all times regarding their reliance on such credit ratings" (Regulation 1060/2009, Preamble, §10). They argue that the formal regulation of CRAs will, at least to some extent, create the (false) impression that now that CRAs are regulated, their ratings will be more reliable. There is a clear risk that investors will continue to rely excessively on the assessment of the CRAs once they are placed under the regulatory regime. Morrison even argues that previous regulations that led to restrictions on financial institutions' portfolios already - to some extent - had this effect: "The adoption of ratingsbased criteria in financial market regulation had a laudable goal: to make better use of market-generated data in regulation. But it had an unintended consequence. When ratings were unregulated, all that the agencies had to sell was their

25 CESR, op. cit., 3.

26 Amtenbrink, F./De Haan, J., op. cit. 
opinion, and they therefore guarded their reputations jealously. The consequence was careful and conservative rating. In other words, introducing a regulator serves to reduce the value of the ratings agency's reputation; regulated agencies are more concerned with maintaining their licence to operate than their reputation for probity. Provided it does not endanger this licence, the rating agency's most rational action is to charge high fees to assist issuers in their search for strong ratings. 27

As the formal regulation of CRAs implies a seal of approval, it will further encourage reliance on ratings by investors who should be conducting their own due diligence, because the Regulation does not include any detailed rules with respect to the methods and models used by the CRAs.

Amtenbrink/De Haan also criticise the Regulation for not changing two fundamental characteristics of the market for CRAs, namely its highly concentrated nature and the financing of the CRAs. As pointed out before, a limited number of CRAs dominate the market, while they are paid by the issuers of financial products and not by investors. Although the Regulation states that "the emergence of new actors on the credit rating agency market should also be encouraged" (Regulation 1060/2009, §55), no specific actions are foreseen in the Regulation in this regard. Goodhart argues in favour of an independent institution, a CRA Assessment Centre (CRAC), whose only task would be to assess the accuracy of CRA estimates and to publish comparative studies of such accuracy. ${ }^{28}$ All CRAs in all countries should be required to place with CRAAC a record of each product rated and a measure of the uncertainty of this rating. This might help competition. As Goodhart argues: "A new entrant could establish a track record for greater accuracy (again independently assessed) in a particular niche by exploiting a comparative advantage, say in rating one particular product line, with a small staff and build from that. What investors want is forecast accuracy. At present they have no simple or straightforward way of checking that [...]. So most investors fall back on reliance on brand names, which reinforces oligopoly." ${ }^{29}$

In amending the Commission proposal, the European Parliament reiterated its position that the possibility of establishing a European public rating agency

27 Morrison, A.D.: Ratings Agencies, Regulation, and Financial Market Stability, mimeo, Saïd Business School, University of Oxford, 2008.

28 Goodhart, C.: The Regulatory Response to the Financial Crisis, Cheltenham, 2009.

29 Ibid, 133. 
should be considered, but the final text of the Regulation does not foresee any steps in this direction, except that the Commission should submit a report that, inter alia, considers alternatives for the "issuer-pays" model (Regulation 1060/2009, §73). The financing of CRAs has been severely criticised in the academic literature. For instance, Portnoy argues that when "the credit rating agency model shifted from investor-pay to issuer-pay, the conditions necessary for the existence of a well-function information intermediary faltered. The agencies faced little or no risk of loss from inaccurate ratings, while the potential gains from inaccurate ratings increased. ${ }^{30}$

\section{Conclusions}

The global financial crisis has triggered a major debate on the effectiveness and efficiency of the current regulatory structures. There is a tendency among policymakers to come up with more and more strict regulation. In this contribution I have questioned this approach. I argue that the widely-shared that more liberalised financial systems are more prone to banking crisis needs to be reconsidered in view of recent studies using better indicators of financial liberalisation. On the other hand, these studies also suggest that adequate supervision of banks will reduce the probability of banking crises. So a balance has to be found between as low a level of regulation as possible and adequate supervision. Unfortunately, it seems that many policymakers nowadays have a tendency for overregulation in an attempt to be seen acting swiftly and decisively in time of crisis, as illustrated by the recently adopted EU Regulation on CRAs. Despite the recommendations of several high profile expert bodies, all of which advised against the introduction of a comprehensive regulatory framework, the EU has adopted new regulation. I doubt whether the new regime will make a decisive difference compared to self-regulation under the IOSCO code. While frequently more specific in terms of its content in some essential regards, the Regulation is not substantially different from the present IOSCO code of conduct. Arguments that have been put forward to give priority to an improvement of the existing framework of selfregulation, while leaving all options open for a future regulatory response in case the former does not sufficiently work, have been dismissed rather quickly. In fact, the new regime can leave the false impression that the ratings of EU regis-

30 Portnoy, F.: Overdependence on Credit Ratings Was A Primary Cause of the Crisis, Fondazione Eni Enrico Mattei Nota di Lavoro, No. 27, 2009 
tered CRAs are more reliable so that investors will continue to rely excessively on the assessment of the CRAs. 